Jurnal Inkofar* Volume 1 No. 2, Desember 2017 * ISSN: 2615-3645 (Print) / 2581-2920 (Online)

Tersedia secara online di: http://www.politeknikmeta.ac.id/meta/ojs/

\title{
PENYUSUNAN ALAT UKUR POTENSI STRES KERJA PERAWAT DENGAN METOE FMEA (FAILURE MODE AND EFFECT ANALYSIS)
}

\author{
Kartika Rahayu Tri Prasetyo Sari dkk ${ }^{1}$, Yosep Satrio Wicaksono ${ }^{2}$, Hisbulloh Ahlis Munawi ${ }^{3}$ \\ ${ }^{1}$ Prodi Teknik Industri, Fakultas Teknik, Universitas Nusantara PGRI Kediri \\ Email: kartikaprasetya0207@gmail.com \\ ${ }^{2}$ Prodi Teknik Industri, Fakultas Teknik, Universitas Nusantara PGRI Kediri \\ Email: otepsawi@yahoo.com \\ ${ }^{3}$ Prodi Teknik Industri, Fakultas Teknik, Universitas Nusantara PGRI Kediri \\ Email: ahlismunawi@gmail.com
}

\begin{abstract}
Nurses have high demands to serve patients for 24 hours for patients to feel always well served. The high demand for work, which often exceeds the ability of the nurse, causes a lot of health complaints on nurses and experiences high levels of work stress. Therefore it is necessary to compose a measuring tool that can know the potential work stress on nurses. so that the factors that can be the main potential of the emergence of work stress can be analyzed to minimize the occurrence of work stress. The purpose of this study is to identify factors that affect work stress on nurses. and compose a measuring tool to know the potential work stress on the nurse using FMEA method. Factors affecting work stress successfully identified the workload and interpersonal relationships, factors that affect work stress then identified with FMEA method and obtained a work stress potential measuring tool containing 12 questions with Likert scale
\end{abstract}

Keywords: Work Stress, Nurse, FMEA

\section{ABSTRAK}

Perawat rumah sakit memiliki tuntutan yang tinggi untuk melayani pasien pada setiap waktu selama 24 jam agar pasien merasa selalu dilayani dengan baik. Tingginya tuntutan kerja, yang seringkali melebihi kemampuan perawat, menyebabkan banyaknya keluhan kesehatan pada perawat dan mengalami stres kerja tingkat tinggi. Oleh karena itu perlu dilakukan penyusunan suatu alat ukur yang dapat mengetahui potensi stres kerja pada perawat sehingga faktor-faktor yang dapat menjadi potensi utama timbulnya stres kerja dapat dianalisis untuk meminimasi timbulnya stres kerja. Tujuan dari penelitian ini adalah mengidentifikasi faktor yang mempengaruhi stres kerja pada perawat. dan menyusun alat ukur untuk mengetahui potensi stres kerja pada perawat dengan menggunakan metode FMEA. Faktor yang mempengaruhi stres kerja berhasil diidentifikasi yaitu beban kerja dan hubungan interpersonal dari faktor yang mempengaruhi stres kerja kemudian diidentifikasi dengan metode FMEA dan diperoleh alat ukur potensi stres kerja yang berisikan 12 pertanyaan dengan skala likert

Kata Kunci: Stres Kerja, Perawat, FMEA

\section{PENDAHULUAN}

Sektor industri jasa dewasa ini berkembang dengan sangat pesat, di mana sektor ini berkontribusi lebih dari 50\% Produk Domestik Bruto dalam ekonomi global (Gecky dkk, 2010) dalam Sari dkk (2017). Industri rumah sakit merupakan contoh sektor jasa yang sedang terus berkembang. Kesehatan pasien merupakan masalah yang sangat penting secara global dalam dunia pelayanan kesehatan. Industri rumah sakit memiliki karakteristik sebagai industri dengan pekerjaan fisik yang berulang, kontrol kerja yang rendah, dan kesempatan untuk peningkatan karier yang kecil (Krause dkk, 1999; Parker dan Krause, 1999; Krause dkk, 2005; Bernhardt dkk, 2003) dalam Sari dkk (2017). Industri rumah sakit, yang memberikan jasa pelayanan kesehatan, diwajibkan untuk beroperasi selama 24 jam nonstop dalam melayani pasien. Karena tidak ada waktu libur beroperasi untuk sektor jasa ini, rumah sakit memberlakukan sistem gilir kerja (shift) bagi karyawannya. Pola kerja shift seperti ini tentu merugikan karyawan karena dapat menyebabkan kelelahan, terutama apabila mendapatkan jadwal dengan istirahat tidak cukup. Menurut Kogi (1985) dalam Baker dkk (2004), karyawan pada industri jasa seringkali mengeluhkan sistem shift yang diberlakukan perusahaan, karena kerja shift 
diasosiasikan dengan kerja yang melelahkan pada shift malam, berdampak pada kesehatan, dan tidak memiliki banyak waktu untuk keluarga dan kehidupan sosial. Pemberi pelayanan kesehatan di rumah sakit yang terdiri dari dokter, perawat, bidan, apoteker, fisioterapis, dan tenaga kesehatan lainnya adalah manusia biasa yang sering melakukan kesalahan pelayanan terhadap pasien dikarenakan stres kerja yang dialami (Sari dkk, 2017). Dalam Depkes RI 2002 dalam Sudarma (2008) dikatakan bahwa perawat professional adalah perawat yang memberikan asuhan keperawatan secara mandiri dan bertanggung jawab serta berkolaborasi dengan tenaga kesehatan lainnya dalam memberikan pelayanan kesehatan. Menganalisa dari definisi tersebut maka perawat memiliki resiko untuk melakukan kesalahan dalam melakukan perawatan terhadap pasien dikarenakan stres kerja yang dialami.

Stres kerja adalah salah satu efek yang dapat dialami oleh seluruh pekerja karena bekerja melebihi batas kemampuan dan dapat berakibat buruk terhadap kesehatan serta kinerja pekerja (Sari dkk, 2017). Penelitian membuktikan adanya korelasi negatif antara stres kerja dengan kualitas pelayanan yang diberikan oleh pekerja, yaitu pekerja dengan tingkat stres yang lebih rendah akan memberikan pelayanan yang lebih baik daripada yang memiliki tingkat stres lebih tinggi (Varca, 1999) dalam Sari dkk (2017). Stres kerja juga dapat mengakibatkan menurunnya kemampuan pekerja untuk belajar (Lepine dkk, 2004) dalam Sari dkk (2017). Menurut Charu (2012) dalam Sari dkk (2017), stres kerja sangat berhubungan dengan menurunnya output kerja, berkontribusi terhadap kecelakaan dan tingkat absen yang tinggi pada pekerja, serta kinerja yang buruk. Padahal kinerja perawat yang buruk akan berpengaruh terhadap performa rumah sakit (Boswell, 2006) dalam Sari dkk (2017), dan sebagai industri jasa seharusnya industri rumah sakit sangat mengedepankan pelayanan dalam mencapai kepuasan pelanggan.

Karena banyaknya keluhan stres kerja pada perawat, diperlukan suatu alat ukur untuk mengetahui potensi stres kerja karyawan. Alat ukur ini diharapkan dapat mengetahui faktor-faktor yang dapat menjadi potensi stres kerja pada perawat, sehingga dapat dilakukan usaha preventif untuk meminimasi tingkat stres kerja pada perawat. Berkurangnya tingkat stres kerja diharapkan dapat meningkatkan kinerja perawat yang akan berakibat baik terhadap performa rumah sakit secara keseluruhan demi mewujudkan kepuasan pasien.

\section{METODE PENELITIAN}

Penelitian yang dilakukan yaitu dengan metode analisis kuantitatif dengan subjek penelitian adalah perawat Rumah Sakit Bayangkara Kediri. Tahapan yang dilakukan pada penelitian ini meliputi:

1. Studi Referensi

Studi referensi dilakukan melalui jurnal untuk mencari permasalahan yang dapat diambil dalam penelitian ini.

2. Perumusan Masalah

Masalah yang diambil dalam penelitian ini adalah analisis faktor-faktor yang dapat mempengaruhi stres kerja dan bagaimana faktor-faktor tersebut mempengaruhinya.

3. Menentukan Tujuan

Tujuan yang akan dicapai dalam penelitian ini adalah mengidentifikasi faktor-faktor yang mempengaruhi stres kerja dan membuat model persamaan hubungan stres kerja dengan faktorfaktor yang mempengaruhinya.

4. Identifikasi Faktor yang Mempengaruhi stres kerja

Identifikasi faktor yang mempengaruhi stres kerja dilakukan melalui studi referensi. Dari studi referensi tersebut didapatkan faktor-faktor yang mempengaruhi stres kerja beserta dimensinya.

5. Pengumpulan Data

Pengumpulan data dilakukan untuk mendapatkan data yang akan digunakan untuk pengolahan data. Data yang dibutuhkan adalah data mengenai variabel-variabel yang telah diidentifikasi sebelumnya. Data yang dibutuhkan berupa data metrik dengan $\mathrm{X}$ dan $\mathrm{Y}$ yang lebih dari satu.

6. Pembagian Data

Data yang telah dikumpulkan akan dibagi menjadi dua untuk pembuatan model dan validasi.

7. Pengolahan Data

Pengolahan data dilakukan dengan statistik multivariat. Untuk membuat instrumen diperoleh dari hasil faktor yang mempengaruhi stres kerja dan ditentuka nilai Risk Priority Number (RPN). 
Jurnal Inkofar* Volume 1 No. 2, Desember 2017 * ISSN: 2615-3645 (Print) / 2581-2920 (Online)

Tersedia secara online di: http://www.politeknikmeta.ac.id/meta/ojs/

8. Analisis Hasil

Hasil yang diperoleh dianalisis untuk mengetahui apakah model instrumen dapat menghasilkan model instrumenn terbaik.

9. Kesimpulan

Langkah terakhir yang dilakukan adalah menarik kesimpulan dari pengolahan data yang telah dilakukan.

\section{HASIL DAN PEMBAHASAN}

3.1 Pengembangan Instrumen

Pengembangan instrumen pengukuran pada penelitian ini dilakukan dengan cara melakukan adopsi dari instrumen penelitian sebelumnya dan studi literatur. Tahap pertama pengembangan instrumen penelitian ini adalah identifikasi variabel. Terdapat satu variabel dalam penelitian ini, yaitu variabel $\mathrm{X}$ mewakili faktor yang mempengaruhi stres kerja. Untuk kuisioner faktor yang mempengaruhi stres kerja diperoleh dari berbagai sumber literatur. Dalam penelitian ini mengidentifikasi faktor yang mempengaruhi stres kerja sebagai variabel independen.

\subsection{Penentuan Faktor yang Mempengaruhi Stres Kerja}

Pada penelitian ini diperoleh dari beberapa literatur yang membahas stres kerja yang terjadi pada perawat sebagai variabel dependen dan faktor yang mempengaruhinya sebagai variabel independen. Tujuan dari menggunakan literatur adalah untuk memperoleh faktor yang paling sering mempengaruhi stres kerja dalam penelitian ini, dan diharapkan memperoleh faktor yang tepat yang mempengaruhi stres kerja. Hasil yang diperoleh dari literatur menghasilkan 3 faktor yang sering mempengaruhi stres kerja dibandingkan faktor yang

\subsection{Pengolahan Data}

Metode regresi linier berganda merupakan metode statistik untuk membuat model matematis hubungan antara stres kerja dengan subdimensi faktor yang mempengaruhi (x). Variabel X yang digunakan dalam model matematis ini lebih dari satu sehingga metode regresi linier berganda cocok untuk digunakan. Regresi linier berganda dapat dilakukan setelah data memenuhi semua uji asumsi regresi linier berganda. Tabel 1 berisi informasi hasil regresi linier berganda stres kerja dengan sub dimensi faktor yang mempengaruhi.

Tabel 1. Korelasi Data $X$

\begin{tabular}{|c|c|c|c|}
\hline \multirow[t]{2}{*}{ Model } & $\begin{array}{l}\text { Standardized } \\
\text { Coefficient }\end{array}$ & Sig. & $\begin{array}{c}\mathrm{R}^{2} \\
\text { Adjusted } \mathrm{R}^{2}\end{array}$ \\
\hline & $\mathrm{B}$ & & \\
\hline (constant) & 1,389 & 0,000 & \\
\hline $\mathrm{X}_{1}$ (beban kerja) & 0,364 & 0,043 & 0,539 \\
\hline $\mathrm{X}_{2}$ (dukungan keluarga) & 0,274 & 0,094 & 0,497 \\
\hline $\mathrm{X}_{3}$ (hubungan interpersonal) & $-0,346$ & 0,043 & \\
\hline
\end{tabular}

Persamaan matematis yang terbentuk adalah $\mathbf{y}=1,389+0,364 \mathrm{X}_{1}-0,346 \mathrm{X}_{3}$. Interpretasinya adalah apabila faktor beban kerja $\left(\mathrm{X}_{1}\right)$ meningkat sebesar satu poin, maka akan terjadi peningkatan stres kerja sebesar 0,364 poin, dan terjadi penurunan stres kerja sebesar 0,346 poin untuk faktor hubungan interpersonal $\left(\mathrm{X}_{3}\right)$ dengan mempertimbangkan kostanta sebesar 1,389. Faktor dukungan keluarga $\left(\mathrm{X}_{2}\right)$ tidak diperhitungkan karena pengaruhnya yang kurang signifikan terhadap stres kerja.

\subsection{Pembuatan Instrumen Pengukuran Stres Kerja}

Setelah faktor yang mempengaruhi stres kerja dipeoleh dari hasil regresi linier yaitu beban kerja dan hubungan interpersonal, maka tahap selanjutnya adalah pembuatan instrumen pengukuran stres kerja dengan metode FMEA. Tujuan pembuatan FMEA umumnya adalah untuk menganalisis karakteristik desain produk berhubungan dengan proses manufaktur yang direncanakan dan desain eksperimen untuk memastikan produk yang dihasilkan sesuai dengan kebutuhan dan ekspektasi konsumen (Villacourt, 1992). Ketika ada resiko cacat atau kegagalan proses, aksi perbaikan dapat diambil untuk mengeliminasi resiko tersebut atau untuk mengurangi potensi terjadinya secara kontinu. 
a) Proses pembuatan FMEA

Urutan pembuatan FMEA adalah sebagai berikut (Wang dan Ho, 2012; Villacourt, 1992):

i. Menentukan faktor potensi resiko (potential failure mode)

Tahap ini bertujuan untuk mengevaluasi apa yang memiliki potensi untuk berjalan secara tidak benar.

ii. Menentukan potensi resiko (potential failure)

Tahap ini bertujuan untuk mengevaluasi resiko apa yang akan terjadi dari setiap faktor potensi resiko.

iii. Menentukan penyebab resiko tersebut (cause for failure)

Tahap ini bertujuan untuk mengevaluasi penyebab dari resiko tersebut.

iv. Menentukan potensi efek yang ditimbulkan (potential effect)

Tahap ini bertujuan untuk mengevaluasi apa efek yang dapat ditimbulkan dari resiko tersebut.

v. Mengevaluasi metode kontrol yang digunakan (availability of control methods)

Tahap ini bertujuan untuk mengevaluasi apakah sudah terdapat metode kontrol untuk mengetahui terjadinya resiko tersebut dan metode apa yang digunakan.

vi. Menentukan langkah untuk meminimalisasinya (suggested measures for improvement)

Tahap ini bertujuan untuk menentukan langkah secara umum yang dapat dilakukan untuk meminimalisasi resiko.

vii. Menghitung Risk Priority Number (RPN)

RPN adalah indikator kritis untuk menentukan mana yang akan menjadi prioritas perbaikan. RPN didapatkan dari perkalian tingkat keparahan (severity), frekuensi terjadinya (occurrence), dan kemudahan mendeteksinya (detection). Semakin kecil nilai RPN yang diperoleh artinya semakin baik. RPN dengan nilai yang tinggi akan dianalisis untuk perbaikan. Tingkat keparahan (severity), frekuensi terjadinya (occurrence), dan kemudahan mendeteksinya (detection) merupakan kriteria dengan skala tertentu yang telah ditentukan sebelumnya.

b) Pembuatan Instrumen Stres Kerja

Dari hasil penguraian faktor yang mempengaruhi stres kerja pada hasil regresi kemudian terbentuklah instrumen untuk mengukur stres kerja dengan metode FMEA dengan tahapan sesuai yang telah dijelaskan pada tahapan metode FMEA, hasil instrumen pengukuran stres kerja dengan metode FMEA terdapat dalam Tabel 2.

Tabel 2. Instrumen Stres kerja

\begin{tabular}{l|l|r|c|c|c|c|c|c|c|c|c}
\hline \multicolumn{1}{|c}{ PERNYATAAN } & 1 & 2 & 3 & 4 & 5 & 6 & 7 & 8 & 9 & 10 \\
\hline 1 & Saya merasa tidak mempunyai semangat & 1 & 2 & 3 & 4 & 5 & 6 & 7 & 8 & 9 & 10 \\
\hline 2 & $\begin{array}{l}\text { Saya merasa tidak tertarik dengan aktivitas saya } \\
\text { sehari-hari }\end{array}$ & 1 & 2 & 3 & 4 & 5 & 6 & 7 & 8 & 9 & 10 \\
\hline 3 & $\begin{array}{l}\text { Saya merasa kehilangan energi dan } \\
\text { kekuatan/tenaga }\end{array}$ & 1 & 2 & 3 & 4 & 5 & 6 & 7 & 8 & 9 & 10 \\
\hline 4 & Saya merasa kurang percaya diri & 1 & 2 & 3 & 4 & 5 & 6 & 7 & 8 & 9 & 10 \\
\hline 5 & $\begin{array}{l}\text { Saya merasa bersalah dan tidak mempunyai hati } \\
\text { nurani }\end{array}$ & 1 & 2 & 3 & 4 & 5 & 6 & 7 & 8 & 9 & 10 \\
\hline 6 & Saya merasa hiduptidak layak untuk dijalani & 1 & 2 & 3 & 4 & 5 & 6 & 7 & 8 & 9 & 10 \\
\hline 7 & Saya merasa sulit konsentrasi & 1 & 2 & 3 & 4 & 5 & 6 & 7 & 8 & 9 & 10 \\
\hline 8 & Saya merasa sangat gelisah & 1 & 2 & 3 & 4 & 5 & 6 & 7 & 8 & 9 & 10 \\
\hline 9 & Saya merasa tenang & 1 & 2 & 3 & 4 & 5 & 6 & 7 & 8 & 9 & 10 \\
\hline 10 & Saya mengalami susah tidur di malam hari & 1 & 2 & 3 & 4 & 5 & 6 & 7 & 8 & 9 & 10 \\
\hline 11 & Saya mengalami nafsu makan berkurang & 1 & 2 & 3 & 4 & 5 & 6 & 7 & 8 & 9 & 10 \\
\hline 12 & Saya mengalami nafsu makan bertambah & 1 & 2 & 3 & 4 & 5 & 6 & 7 & 8 & 9 & 10 \\
\hline
\end{tabular}


Jurnal Inkofar * Volume 1 No. 2, Desember 2017 * ISSN: 2615-3645 (Print) / 2581-2920 (Online)

Tersedia secara online di: http://www.politeknikmeta.ac.id/meta/ojs/

\section{KESIMPULAN}

Kesimpulan yang didapatkan dari laporan ini adalah sebagai berikut.

1. Faktor yang mempengaruhi stres kerja adalah beban kerja dan hubungan interpersonal.

2. Instrumen pengukuran stres kerja telah berhasil dibuat dengan metode FMEA dengan penentuan RPN

\section{DAFTAR PUSTAKA}

Baker, A, Roach, G, Ferguson, S \& Dawson, D, 2004, 'Shiftwork experience \& the value of time', Ergonomics, vol. 47, no. 3, pp. 307-317.

Beehr, TA dan Newman, JE, 1978, 'Job stress, employee health and organizational effectiveness: a facet analysis, model and literature review', Personnel Psychology, vol. 31, pp. 665-699

Bernhardt A, Dresser L \& Hatton E, 2003, 'The coffee pot wars: Unions and firmrestructuring in the hotel industry', dalam Appelbaum E, Bernhardt A, Murnane RJ (ed), Low-wage America: How employers are reshaping opportunity in the workplace, Russell Sage Foundation, New York.

Boswell, GH, Kahana, E \& Dilworth-Anderson, P, 2006, 'Spirituality and healthy lifestyle behaviors: Stress counter-balancing effects on the well-being of older adults', Journal of Religion \& Health, vol. 45, no. 4, pp. 587-602.

Charu, M 2012, 'Occupational Stress and Its Impact on QWL with Specific Reference to Hotel Industry', Advance in Management, vol. 5, no. 9, pp. 50-54.

Cox, T, Griffiths, A, Houdmont, J, 2006, Defining a case of work-related stress, Research Report, Health \& Safety Executive.

Gecky, P, Izumi, N \& Hasida, K, 2010, 'Service science, quo vadis', International Journal of Service Science, Management, Engineering, and Technology, vol. 1, no. 1, pp. 1-16

Krause, N, Scherzer, T \& Rugulies R, 2005, 'Physical Workload, Work Intensification and Prevalence of Pain in Low Wage Workers: Result from a Participatory Research Project with Hotel Room Cleaners in Las Vegas', American Journal of Industrial Medicine, pp. 1-12.

Lepine, JA, Podsakoff, NP, Lepine, MA, 2005, 'A meta-analytic test of the challenge stressorhindrance stressor framework: an explanation for inconsistent relationships among stressors and performance', Academy of Management Journal, vol. 48, no. 5, pp. 764-775.

Malik, N, 2011, 'A Study on Occupational Stress Experienced by Private and Public Bank Employess in Quetta City', African Journal of Business Management, vol. 5, no. 8, pp. 3063-3070.

Sari. K.R.T.P, Munawi. H.A, Wicaksono. Y.S, 2017' Aplikasi Principal Component Analysis (PCA) untuk Mengetahui Faktor yang Mempengaruhi Stres Kerja, Prosiding Snatika, STIKI, Malang.

Villacourt, M, 1992, Failure Mode and Effects Analysis (FMEA): A Guide for Continuous Improvement for The Semiconductor Equipment Industry, International Sematech, Inc 